\title{
CAN ECOTOURISM SUCCEED A SUSTAINABLE LIVELIHOOD: THE IMPORTANCE OF FISHERMEN'S INVOLVEMENT IN CILETUH GEOPARK
}

\author{
Dina Lianita Sari"), Fitria Dewi Raswatie ${ }^{* 1}$, Danang Pramudita*), Leonita Dwiyanto*), \\ Akhmad Fauzi*), Osmaleli*)
}

${ }^{*}$ Department of Resource and Environmental Economics, Faculty of Economics and Management, IPB University Jl. Agatis, IPB Dramaga Campus Bogor 16680, Indonesia

\begin{abstract}
Ciletuh in Sukabumi area was inaugurated as a Global Geopark by UNESCO in 2017, and has many potential natural resources such as Palangpang Beach as a leading tourism area of Ciletuh Geopark. Palangpang Beach in Ciletuh Bay is also an estuary area used by fishermen to collect fish in Fish Auction (TPI). Fishermen on Palangpang Beach are categorized as small fishermen according to the size of the capture fishery units, which results in the fishermen on Palangpang Beach prefer to take part in tourist activities by chartering boats for tourists to increase their income. The objectives of the study were to investigate the impact of Geopark establishment on fishermen's livelihood and to establish ecotourism development strategies in supporting the sustainable livelihood. The method used for sustainable livelihood analysis was descriptive analysis. The results showed that increased sustainable livelihood assets of fishermen were found in human capital, social capital, physical capital, and economic and financial capital, while natural capital assets declined. The Geopark Ciletuh development strategy to improve the sustainable livelihood can be performed through the fishermen involvement in capture fishery and Geopark tourism management such as by becoming a tour guide, a fishing trainer, an educator who educates on fishing weather in fisheries, a mangrove planter, and a coral reef educator.
\end{abstract}

Keywords: capital asset, geopark, descriptive analysis, ecotourism, fish auction

\begin{abstract}
Abstrak: Ciletuh merupakan kawasan di Sukabumi yang diresmikan sebagai Global Geopark oleh UNESCO pada tahun 2017, dan memiliki banyak potensi sumberdaya alam salah satunya Pantai Palangpang yang menjadi kawasan wisata unggulan Geopark Ciletuh. Pantai Palangpang membentuk teluk ciletuh dan muara dari Sungai yang dimanfaatkan oleh nelayan untuk mendaratkan ikan dan Tempat Pelelangan Ikan (TPI). Nelayan di Pantai Palangpang dikategorikan nelayan kecil menurut unit kepemilikan kapal, sehingga nelayan mengikuti kegiatan wisata berupa penyewaan kapal kepada wisatawan untuk meningkatkan pendapatannya. Tujuan penelitian adalah untuk menganalisis dampak dari adanya Geopark Ciletuh terhadap mata pencaharian nelayan dan untuk merumuskan strategi pengembangan ekowisata dalam mendukung sustainable livelihood. Metode penelitian yang digunakan adalah sustainable livelihood analysis dan analisis deskriptif. Hasil penelitian menunjukkan bahwa aset sustainable livelihood mengalami peningkatan pada modal manusia, modal sosial, modal fisik, dan modal ekonomi dan finansial, sedangkan modal natural menurun. Strategi pengembangan Geopark Ciletuh dalam meningkatkan sustainable livelihood dapat dilakukan melalui pelibatan nelayan tidak hanya dalam melakukan perikanan tangkap, namun juga dalam pengelolaan wisata Geopark seperti menjadi pemandu wisata, memberikan pelatihan memancing, pendidikan mengenai cuaca melaut dalam perikanan, penanaman mangrove, pendidikan terumbu karang.
\end{abstract}

Kata kunci: aset kapital, Geopark, analisis deskriptif, ekowisata, pelelangan ikan

\footnotetext{
${ }^{1}$ Corresponding author:

Email: fitria.dewi@apps.ipb.ac.id
} 


\section{INTRODUCTION}

Ecotourism has become one of tourism trends that continues to develop lately (Butarbutar and Soemarno, 2013). Ecotourism is an economic activity based on the preservation of ecological functions and services as amenity services (Yulianda, 2007). One of tourism activities with many potentials in Indonesia is coastal and marine tourism. Marine ecotourism as ecotourism that utilizes the character of coastal and marine resources extremely depends on the available natural resources. Marine ecotourism activities can be water-based tourism, land-based tourism, or a combination between water- and land-based tourism, which includes marine life observation, diving, snorkeling, seabed observation trip, also coastal and beach walks (Elliott et al. 2007). Based on these characteristics, tourists who are mainly in coastal and marine natural tourism can find different new experiences for each individual to make their lives more meaningful to inspire and enable them to raise their consciousness (Nurhayati et al. 2019; Nugroho et al. 2016).

Ecotourism as part of tourism industries has multiproduct characteristics (goods and services) in the service availability, which can produce an economical profit for the involved actors (Nirwandar, 2005). The economic profit gained affects the income and livelihood improvements for individuals who are involved directly and indirectly in tourism activity. Ciletuh Geopark in Sukabumi was inaugurated as a Global Geopark by UNESCO in 2017. The Ciletuh Geopark has abundant natural resource potentials as one of which is Palangpang Beach. Palangpang Beach forms Ciletuh Bay and estuary that are utilized by the fishermen to land and collect the fish in Fish Auction (TPI). As a conservation area appointed globally, the tourism management in Ciletuh Geopark is directed on the ecotourism approach by putting upfront the local community involvement.

This is in accordance with research conducted by Bakar dan Wall (2018), ecotourism, probably the fastestgrowing form of tourisminremote natural areas, provides an economic rationale for proponents of national parks although there are many critiques of its effectiveness in sustaining local people's livelihoods and, at the same time, conserving biodiversity. Moreover, Arroyo and Fernandez (2016), ecotourism growth in protected area as natural preservation area can offer conceptual advantages in three dimensions: Ecological advantages, economic benefits, and social benefits. Ecotourism plays an empirical role in four conservation indices, such as funding, education, ethics, and protection of natural resources (Arlym and Hermon, 2019). From the economical aspect, ecotourism may also contribute to growing local collectivity employment, the number of working people, infrastructure development, and community involvement (Nurhayati et al. 2019, Hitchner et al. 2009). Ecotourism is an alternative way to conserve natural resources and provides a solution for the poverty problem in coastal areas at the same time.

Fishermen in Palangpang Beach, Ciwaru Village as part of Ciletuh Geopark have existed since 1957. Fishermen in Palangpang Beach are categorized as small-scaled fishermen due to a dominantly low boat power machine which is below 5 GT (Gross Ton). Before the Palangpang Beach was appointed as part of Ciletuh Geopark, fishermen only depended their livelihood on fish capture. The fish capture produced by small fishermen is closely affected by several factors, such as weather conditions, increased production cost, and increased number of fishermen. This condition causes the small-scaled fishermen's fish capture products to fluctuate which influences the fishermen's income. Although the fishery products are relatively fluctuating, the fish capture products for fishermen often become the livelihood of last-resort due to this sector characteristic that are open-access and relatively small cost to begin this activity (Bene, 2003). In contrast, a study conducted by Bakar and Wall (2018) found that community livelihood activities had not changed in any way before and after the establishment of marine national park. Only a small number of residents said that their livelihood was currently good and they were engaged in alternative livelihood activities.

Thefishermeninvolvementintourismactivityprincipally can become an alternative income source for fishermen, mainly for small fishermen. Fishermen gain appropriate income when the fishery capture product decreases. This income substitution can improve the fishermen's resilience (Standford et al. 2017). Menenghello and Mingoto (2016) mentioned that if fishermen provided facilities for the tourism sector supported by regulations and local community in tourism development, then this activity could be sustainable socially, economically, and environmentally. Tiypan and Mee-Udon (2014) showed that the local fishermen should utilize available assets or capital well. 
Coastal area development closely depends on the available natural resource utilizations of the coastal area. The activity development performed apart from fish capture in coastal area can be tourism activity as an optimization coastal resource utilization effort (Duarte et al. 2008). Therefore, activity developments in coastal area must be considered based on the ecological, socio-economic, and institutional aspects. These considerations will lead to sustainable utilization of the potential coastal natural resources and ensure the coastal community economy. This paper aimed (1) to investigate the impact of geopark establishment on fishermen's livelihood; and (2) to establish ecotourism development strategies in supporting the sustainable livelihood.

\section{METHODS}

Primary data were obtained from direct interviews with questionnaire to fishermen respondents on February March, 2019 in Palangpang Beach, Palangpang vicinity, Ciwaru Village, Ciemas Sub-district, Sukabumi District. The location was selected purposively, considering that the location is part of Ciletuh Geopark development, which contains fish capture activity by the local fishermen. Secondary data were obtained from the Central Bureau of Statistics (BPS), Ciwaru Fish Auction (TPI), and other relevant literatures.

Ciletuh Geopark impact was analyzed using the sustainable livelihood analysis, while Ciletuh Geopark development strategy to support sustainable livelihood was analyzed by qualitative description. In terms of sustainable livelihood analysis, we gathered data from 81 respondents where those people were chosen by using a purposive sampling of the total population at 420 fishermen.

The livelihood approach locates the community as a development center, and the framework of sustainable livelihood assists in grouping how the inhibition and opportunity connect each other (Saragih et al. 2007). The capital criteria used in the study was based on Mutahara et al. (2016), Widyastuti (2017), Triyanto and Firdaus (2016), Prasetiamartati et al. (2006), Martopo et al. (2013), Stanford et al. (2017). There were five capital category assets compared from before and after the Ciletuh Geopark development project occurred (Table 1).
Table 1. Sustainable livelihood aspect used in the study

\begin{tabular}{|c|c|}
\hline Aspect & Criteria \\
\hline $\begin{array}{l}\text { Human } \\
\text { Capital }\end{array}$ & $\begin{array}{l}\text { Health facility, health level, family } \\
\text { education level, education level, fishing } \\
\text { experience }\end{array}$ \\
\hline $\begin{array}{l}\text { Natural } \\
\text { Capital }\end{array}$ & $\begin{array}{l}\text { Fish capture production/number of fish } \\
\text { capture, air quality, waste condition, clear } \\
\text { water access, water quality that affected } \\
\text { the fish capture }\end{array}$ \\
\hline Social Capital & $\begin{array}{l}\text { Conflict, fish capture usage, local } \\
\text { government impact on fishermen, } \\
\text { fisherman group availability, marketing } \\
\text { system }\end{array}$ \\
\hline $\begin{array}{l}\text { Physical } \\
\text { Capital }\end{array}$ & $\begin{array}{l}\text { Boat ownership, fish selling facility } \\
\text { (TPI), fishermen landing area in Ciletuh } \\
\text { Bay/fish landing location, road access, } \\
\text { number of providers (handphone } \\
\text { communication provider signal) }\end{array}$ \\
\hline $\begin{array}{l}\text { Economic } \\
\text { and Financial } \\
\text { Capital }\end{array}$ & $\begin{array}{l}\text { Subsidy level, saving development, } \\
\text { capital, profit change ratio, worker } \\
\text { absorption }\end{array}$ \\
\hline
\end{tabular}

Each capital asset had indicators to measure the change level based on the respondent's perception or view on each capital asset indicator. Respondents were provided indicator selection scale from the worst to the best. Scale (A) demonstrated the best condition, scale (B) demonstrated less good condition, scale (C) demonstrated quite good condition, scale (D) demonstrated good condition, and scale (E) demonstrated the best condition. The sustainable livelihood value determination step was performed by, first, providing value weight on respondent's selection scale to observe each asset indicator level. Based on Udayakumura and Shresta (2011) and Longpichai et al. (2012), the weight provided for each criterion indicator can be seen in Table 2 .

Table 2. Sustainable livelihood asset indicator weight value

\begin{tabular}{cc}
\hline Selection indicator & Weight \\
\hline A & 0 \\
B & 0.25 \\
C & 0.50 \\
D & 0.75 \\
E & 1 \\
\hline
\end{tabular}

Second, the index value for each capital asset criterion was mathematically calculated based on the following formula (Miah, 1993 in Udayakumura dan Shresta, 2011): 


$$
\operatorname{Index}(\operatorname{In})=\sum \frac{x_{i} w_{i}}{N}
$$

Note: Index (In) (Capital asset criteria value $(0 \leq \operatorname{Index} \leq 1)) ; \quad x_{i} \quad$ Fisherman respondent selection indicator level); $\mathrm{w}_{\mathrm{i}}$ (Weight for each indicator selected by the fisherman respondent); $\mathrm{N}$ (Total of fisherman respondents); $\mathrm{i}$ (i-th individual $(\mathrm{i}=1,2,3, \ldots, \mathrm{n})$ ).

Third, after each capital criterion index value was calculated, the capital asset value was measured with the following formula (Chen et al. 2012):

$$
C=\sum_{n=0}^{N} \frac{I n}{T n}
$$

Note: C (Asset score $(0 \leq \mathrm{C} \leq 1)$ ); $\operatorname{In}$ (Capital asset criteria value); Tn (Total of criteria abundance in each asset (5 criteria)).

Fourth, the sustainable livelihood aspect value was determined with a formula following Chen et al. (2012):

\section{$\mathrm{LA}=(\mathrm{Ch}+\mathrm{Cn}+\mathrm{Cs}+\mathrm{CP}+\mathrm{Cef}) / 5$}

Note: LA (Sustainable livelihood value in arithmetic mean); Ch (Human capital value); Cn; (Natural capital value); Cs (Social capital value); $\mathrm{Cp}$ (Physical capital value); $\mathrm{Cef}$ (Economic and financial capital value).

The formula to calculate the asset score (C) and sustainable livelihood value (LA) is an arithmetic mean formula, but the geometric mean condition was more appropriate to be used in arithmetic average (Misra and Gupta, 2010) in Perdana (2018). The geometric mean can be used as a middle value for ratio mean, percentage, and change level in one period compared to other periods. The geometric mean was calculated with the following equation:

$$
G M=\sqrt[N]{X_{1} X_{2} \ldots X_{N}}
$$

Note: GM (Sustainable livelihood value in geometric mean); N (Number of capital criteria); Xi (i-th capital value $\left(\mathrm{X}_{1}, \mathrm{X}_{2}, \ldots \mathrm{X}_{5}\right)$.

The geometric mean result was compared to the asset score formula result (C) and sustainable livelihood value (LA) using the arithmetic mean to identify the value difference and status obtained. The sustainable livelihood value was calculated on the condition before and after the Ciletuh Geopark areal development in 2015 and 2019. The sustainable livelihood determination status (Miah, 1993 in Longpichai et al. 2012) can be seen in Table 3.

Table 3. Sustainable livelihood status value criteria

\begin{tabular}{cc}
\hline Value & Status \\
\hline $0.00-0.33$ & Low \\
$0.34-0.66$ & Medium \\
$0.67-1$ & High \\
\hline
\end{tabular}

\section{RESULTS}

\section{The Impacts of Geopark Establishment on Fishermen's Livelihood}

Sustainable livelihood is an approach to identify, design and assess new initiatives (projects and programs). This framework is used to reassess the activities that have been carried out and provide information for policy makers and research purpose inputs. As an example of research conducted in Zambia and India, planned infrastructure and watershed projects were reviewed and substantially modified after considering the sustainable livelihood assets (Ashley and Carney, 1999).

The sustainable livelihood assets analyzed were human capital, natural capital, social capital, physical capital, and economic and financial capital. The capital asset was used to identify and assess the impact of the Ciletuh Geopark tourism development project on the sustainable livelihood assets of fishermen in Ciwaru Village. The Ciletuh Geopark was inaugurated by UNESCO in 2017; thus, the capital assets identified in 2015 and 2019 before and after the Ciletuh Geopark was established (Table 4). As explained in the methods section, we compute arithmetic mean and geometric mean in obtaining sustainable livelihood value. In several cases, geometric mean can clarify sustainable livelihood assets better than arithmetic mean. For example, economic and financial capital in arithmetic mean had the same sustainability status before and after Ciletuh Geopark was established, while geometric mean captured status shifting from high to medium. Moreover, both sustainable score and status in arithmetic mean increase, while sustainable score in geometric mean decrease and the status has not changed. 
Table 4 shows sustainable livelihood scores based on arithmetic and geometric mean in order to get information whether fishermen obtained increased value or status. In terms of arithmetic mean, physical capital has a significant increase that can be seen in deviation value. Furthermore, assets of human capital, social capital, physical capital, and economic and financial capital have increased in value, while natural capital has decreased in value. Based on the geometric mean, the value of sustainable livelihoods has decreased in value, although it remains at a medium status. It is due to economic and financial capital has decreased in status and high value, because decreased fishermen's income and fisherman surplus which affect the value and final status of sustainable livelihoods.

Physical capital includes basic infrastructure such as roads and transport facilities, shelter, sanitation, water, energy and communication facilities, the production equipment and the means which enable people to pursue their livelihoods (Kleih et al. 2003). Physical capital assets experienced the greatest increase, because physical capital was included in the most developed infrastructure capital due to the development of the Ciletuh Geopark. The geopark development has an impact on the development of better road infrastructure, and makes it easier for fishermen and sellers to distribute fish capture. This result is in line with Worowirasmi and Aryiningsih's research (2018) which found that road access is an important capital. In addition, the government infrastructures that had been built, like public mosques, public sanitation, and communal wells, could attract outside traders to operate in fish auction facilities.

Other capital assets, namely human capital, social capital, and economic and financial capital, have increased in value, while natural capital has decreased both in value and sustainability status. This is because there is a decrease in the number of catches, the accumulation of garbage on the beach and in the sea affecting fishing activities. The results of value change of the fishermen's sustainable livelihood are also depicted in pentagon asset which can be seen in Figure 1.

Table 4. Value of sustainable livelihoods based on arithmetic mean and geometric mean

\begin{tabular}{|c|c|c|c|c|c|}
\hline \multirow{2}{*}{ Sustainable livelihood assets } & \multicolumn{2}{|c|}{ Before } & \multicolumn{2}{|c|}{ After } & \multirow{2}{*}{ Deviation } \\
\hline & Score & Status & Score & Status & \\
\hline \multicolumn{6}{|l|}{ Arithmetic Mean } \\
\hline Human capital & 0.77 & $\mathrm{H}$ & 0.79 & $\mathrm{H}$ & 0.02 \\
\hline Natural capital & 0.68 & $\mathrm{H}$ & 0.63 & M & -0.05 \\
\hline Social capital & 0.64 & M & 0.68 & $\mathrm{H}$ & 0.04 \\
\hline Physical capital & 0.50 & M & 0.68 & $\mathrm{H}$ & 0.18 \\
\hline Economic and financial capital & 0.60 & M & 0.64 & M & 0.04 \\
\hline Sustainable Livelihood Score & 0.64 & $\mathrm{M}$ & 0.69 & $\mathrm{H}$ & 0.05 \\
\hline \multicolumn{6}{|l|}{ Geometric Mean } \\
\hline Human capital & 0.70 & $\mathrm{H}$ & 0.77 & $\mathrm{H}$ & 0.07 \\
\hline Natural capital & 0.66 & M & 0.57 & M & -0.09 \\
\hline Social capital & 0.62 & M & 0.66 & M & 0.04 \\
\hline Physical capital & 0.44 & M & 0.67 & $\mathrm{H}$ & 0.23 \\
\hline Economic and financial capital & 0.76 & $\mathrm{H}$ & 0.47 & M & -0.29 \\
\hline Sustainable Livelihood Score & 0.63 & $\mathrm{M}$ & 0.62 & $\mathrm{M}$ & -0.01 \\
\hline
\end{tabular}

Note: $\mathrm{H}=$ high, $\mathrm{M}=$ medium; Deviation is calculated by subtracting score before from score after. 
Figure 1 shows changes in each capital from 2015 and 2019 , namely before and after the development of the Ciletuh Geopark. The capital asset that experienced the most improvement was physical capital due to infrastructure development. The geopark development impacts development of better road infrastructure. The condition of the previous access road was in rocky and gravel, but after the Ciletuh Geopark was established, there was tourism development and one of them was upgrading the road infrastructure into asphalt roads. The road infrastructure development is intended to facilitate tourism activities in Ciletuh, but there is a multiplier impact with the construction of road infrastructure. Fishermen stated that it was easier to distribute fish capture for both short and long distances. Sellers distributing fish to Pelabuhan Ratu, if previously travelled by sea for 8 hours, can cut the transportation time and be faster by using land for less than 4 hours. This is beneficial for fishermen and sellers since it can reduce travel costs incurred for distribution of catches. Another infrastructure that has improved is communication access, namely the number of providers or signal providers of mobile phone communication services to access information via the internet, and other means of communications. Before geopark development there were only 1 to 2 providers available, after geopark development there were more than 2 providers available. Therefore, the community and fishermen have more opportunities to communicate, there is even a wi-fi spot in the tourist area of Palangpang Beach.
Social capital has increased because conflicts between fishermen do not occur often, the use of environmentally friendly fishing gear, income tax policies that are considered not detrimental, groups of fishermen that have a positive impact in the form of machine assistance, and a marketing system with auctions that are considered good to conduct. This finding confirms study conducted by Worowirasmi and Aryiningsih (2018) who claimed that social capitals was important variable in pursuing the sustainable livelihood. Social capitals developed through networks and connectedness could increase people's trust and ability to work together and expand their access to wider institutions. Other ways were from trust, reciprocity, and exchanges that facilitate co-operation could reduce transaction costs and might provide the basis for informal safety nets amongst the poor.

The increase in human capital is due to the availability of adequate health facilities, although the level of fisherman's health has decreased with increasing age of fishermen. The education level of fishermen's families has increased, supported by available educational facilities. Increased economic and financial capital due to the ability in sufficient capital, and high absorption of labor. This confirms study conducted by Kleih et al. (2003) that financial capital was a versatile type of capital which could be used to obtain other livelihood capitals.

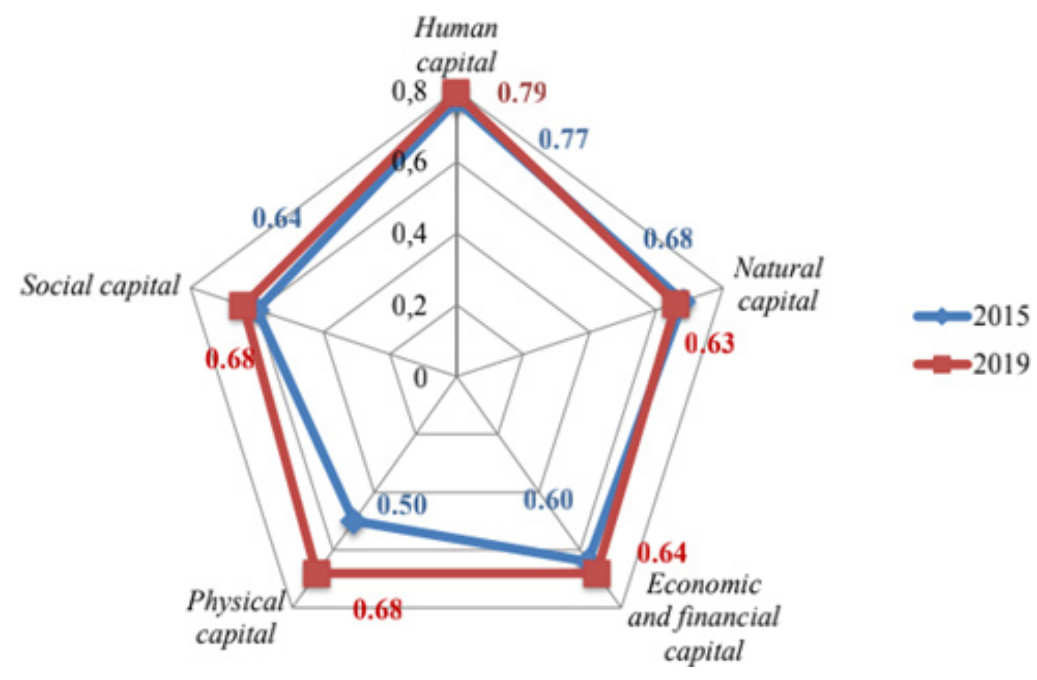

Figure 1. Diagram of fishermen's sustainable livelihood at Ciwaru Village (arithmetic mean) (Notes: Values in blue and red are based on Table 4). 
The results of value changes on the sustainable livelihood assets of fishermen based on the geometric mean can be seen in Figure 2. The results of the sustainable livelihood value using the geometric mean with a comparison of the value of conditions before the development of Ciletuh, fisherman's economic and financial capital was in high status, due to the high status of capital subsidies and the fishermen's capital capacity. The decline in value was quite high due to a decrease changes in fishermen's income and fisherman surplus from medium to low status. Based on the results of interviews with fishermen, most fishermen feel a decrease in income in fisheries business. Due to increase operational costs along with the increase in fuel prices. Before the geopark was established, the price of fuel was Rp8,000 per liter, but after the development of the geopark the price of fuel became Rp10,000 per liter led to an increase in costs. Another factor is the increasing competition among fishermen which reduces the number of fish capture.

\section{Ecotourism Development Strategies in Supporting Sustainable Livelihood}

Based on observations, fishermen from Palangpang Beach, Ciwaru Village, experienced a decrease in producer surplus or decreased welfare, and had incomes below the Sukabumi Regency Minimum Wage. This is due to the decrease in the number of fisherman catches, thereby reducing revenues and increasing operational costs. Alternative management recommendations for the fisheries sector are increasing access to capital, increasing the role of community institutions, producing fishery products and community-based fishing industries, and opening access to markets.

Increasing access to capital can be performed by establishing partnership with various national and regional banking institutions to assist in accessing fishery capital. The role of community institutions also needs to be improved, namely involving all fishermen in fishing groups or fishermen's cooperatives. All fishermen are expected to benefit in the form of machine assistance through fishing groups and cooperatives. Fishermen and community produce derivative or processed fishery products, which become the Ciletuh fishermen or fishery sector signature characteristics. Fishermen establish a fishery processing industry utilizing all the local resources; thus, the benefits can be felt by the local community. Fishermen, TPI Ciwaru management and related parties open access to the market by bringing the community's products closer to big companies that export fishery commodities.

Palangpang Beach is one area that is in great demand by tourists after the development of the Ciletuh Geopark. This is used as an opportunity by fishermen to increase their income, by providing businesses for marine tourism activities to tourists. Marine tourism business activities have been carried out by fishermen for the last two years, since the Ciletuh Geopark was inaugurated in 2017. The contribution of tourism or the share of fishermen's income from marine tourism to the total income of fishermen's households is not large. Therefore, the involvement of fishermen in the management of the Ciletuh Geopark needs to be expanded.

Marine ecotourism is potential to be used as a livelihood alternative, because the community has extensive local knowledge and detailed about environmental condition and coastal resources (Subagiana et.al, 2017). The tourism sector, in this case the Ciletuh marine tourism and the fishery sector, is a good combination to support capture fisheries sector actors, namely fishermen, especially by providing opportunities for fishermen to increase their income. Alternative recommendations for the management of the tourism sector and the fisheries sector are that the local government and the central government are expected to be able to jointly create policies for the development of the Ciletuh Geopark in the integrated fisheries and tourism sector. The local government, and the Ciletuh Geopark tourism manager provide tour scheme or tour package for visitors which tourist guides are fishermen and the local community. Tourism management can create a tourism scheme in the form of an integrated tour schedule; thus, tourists get education and entertainment, and fishermen get jobs. The tour schedule can be fishing training, education about the weather for sea fishing, mangrove planting, coral reef education, and others. These strategies are similar with research conducted by Subagiana et al. (2017) that improving cooperation with domestic and foreign travel agents and providing an information center related to marine ecotourism activities can improve the involvement of fishermen to get sustainable livelihood. 


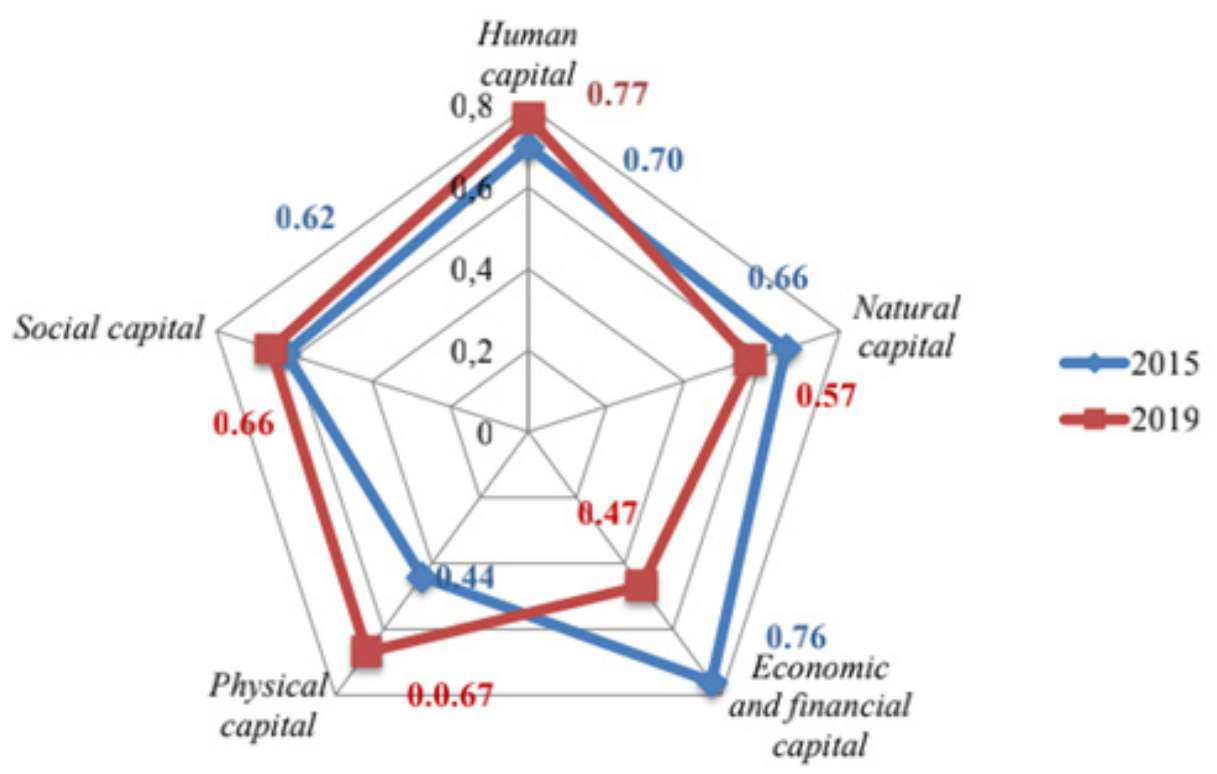

Figure 2. Diagram of fishermen's sustainable livelihood at Ciwaru Village (geometric mean) (Notes: Values in blue and red are based on Table 4).

Other alternative policies are local governments, tourism management, and fishermen to develop tourism products related to fisheries. Market segmentation and promotion in tourism, the Sukabumi Government forms a tourism market segmentation that can be reached by all levels of society while still considering environmental sustainability. Promotion of tourism through various media and involving the private sector in investment. Local governments and tourism management can give training to fishermen to improve fishermen's skills in guiding tourist and ensuring adequate quality according to tourism service standards. This can open up other job opportunities for fishermen, thereby reducing the competition among fishermen in the production of fish capture at the sea.

\section{Managerial Implications}

The results show that the existence of five livelihood assets is very important in supporting the fishermen's livelihood system, so that the strategic mapping for managerial aspects carried out in this study is based on the sustainability score of each asset. One of the important assets that need to be managed properly is human resource assets. This asset has a high sustainability status both before and after the development of the Ciletuh geopark. The educational aspect needs to be especially for tourism activities where efforts to maintain the sustainability status of this aspect can be done by providing hospitality training as part of tourism services to strengthen the knowledge possessed from experience and formal education.
Physical assets prior to the establishment of the Ciletuh geopark has a medium sustainability status and shift to a high sustainability status. However, in order to support the strategy of integrating fisheries and tourism, improvements in facilities and management of fish auction facilities and ship parking facilities are needed.

The last asset that needs attention to be managed properly is economic and financial capital, especially in revenue and savings management. Increasing sources of income must make fishermen smarter in managing sources of income and can allocate savings. Strengthening family financial management on the micro aspect is a basic important thing for fishermen. In the end, the managerial efforts towards the management of livelihood assets are expected to strengthen the ecotourism development strategy in order to support the sustainable livelihoods of fishermen.

\section{CONCLUSIONS AND RECOMMENDATIONS}

\section{Conclusions}

Sustainable livelihood assets have changed in value and status, namely assets that have increased are human capital, social capital, physical capital, and economic and financial capital, while natural capital has decreased, due to a decrease in the number of fish capture. There is a difference in the final value status of sustainable livelihoods using the geometric mean due 
to high declination in economic and financial values, followed by decreased profit changes from medium to low status, that affect the value of the economic and financial status of fishermen.

The Ciletuh Geopark development strategy in improving sustainable livelihoods can be carried out through the involvement of fishermen not only in capture fisheries, but also in managing Geopark tourism such as being a tour guide, providing fishing training, education about weather for sea fishing, mangrove planting, and coral reef education. To support this, the government and tourism management can provide training to fishermen to increase capacity and quality that meets tourism service standards. This conclusion strengthens the finding that development of marine ecotourism serves as an alternative livelihood for society and involvement of fishermen is important to gain sustainability in marine people livelihood, because they have wide and detailed local knowledge about the coastal environment.

\section{Recommendations}

The management of Ciletuh Geopark marine tourism can be carried out in an integrated manner with cooperation between the local government and fishing groups; hence, fishermen can make the best use of marine tourism potential as additional income and be part of the development of Ciletuh Geopark marine tourism. The local government can develop alternative livelihoods aimed not only at fishermen, but also for fishermen's families, such as fishermen's wives, the majority of whom do not have jobs. The development of alternative livelihoods is not only in the fishery sector such as fish processing, but can also be fish cultivation, marketing of derivative products, even in non-fisheries sector.

\section{REFERENCES}

[UNESCO] United Nations Educational, Scientific and Cultural Organization. 2018. What is a UNESCO global geopark. http://en.unesco.org. [10 Jan 2019].

Arlym L, Hermon D. 2019. Strategy of ecotourism development in Pariaman City. IOP Conf. Ser. Earth Environ. Sci 314: 12039.https://doi. org/10.1088/1755-1315/314/1/012039.

Ashley C, Carney D. 1999. Sustainable Livelihood: Lessons From Early Experience. London: Russel
Press.

Bene, C. 2003. When fishery rhymes with poverty: a first step beyond the old paradigm on poverty in small-scale fisheries. World Development 31(6): 949-975.https://doi.org/10.1016/S0305750X(03)00045-7.

Butarbutar R, Soemarno S. 2013. Environmental effects of ecotourism in Indonesia. Journal of Indonesian Tourism and Development Studies 1(3): 97-107.https://doi.org/10.21776/ ub.jitode.2013.001.03.01.

Chen H, Zhu T, Krott M, Calvo JF, Ganesh SP, Makoto I. 2012. Measurement and evaluation of livelihood assets in sustainable forest commons governance. Land Use Policy 30(2013): 908-914.https://doi. org/10.1016/j.landusepol.2012.06.009.

Duarte et al. 2008. The charisma of coastal ecosystems: addressing the imbalance. Estuaries and Coasts 31: 233-238. https://doi.org/10.1007/s12237008-9038-7.

Elliott G, Mitchell B, Wiltshire B, Manan A, and Wisme S. 2001. Community participation in marine protected area management: Wakatobi National Park, Sulawesi, Indonesia. Coastal Management 29(4): 295-316. https://doi. org/10.1080/089207501750475118.

Hitchner SL et al. 2009. Community-based transboundary ecotourism in the Heart of Borneo: a case study of the Kelabit Highlands of Malaysia and the Kerayan Highlands of Indonesia. Journal of Ecotourism 8(2):193-213. https://doi.org/10.1080/14724040802696064.

Longpichai O, Perret SR, Shivakoti GP. 2012. Role of livelihood capital in shaping the farming strategies and outcomes of smallholder rubber producers in Southern Thailand. Agriculture 41(2):117-124. https://doi.org/10.5367/oa.2012.0085.

Martopo A, Hadirman G, Suharyanto. 2012. Kajian tingkat penghidupan berkelanjutan (sustainable livelihood) di kawasan dieng (kasus di Dua Desa Kecamatan Kejajar Kabupaten Wonosobo). Journal EKOSAINS 5(2):47-56.

Menenghello S, Mingotto E. 2016. Promoting sustainable development through fisheriesrelated tourism experiences. benefit from the integration between fisheries and tourism in venetian coastal areas. Intenational Centre of Studies on Tourism Economics 11(3):447-457.

Mutahara M, Haque A, Khan MSA, Warner JF, Wester F. 2016. Development of a sustainable livelihood security model for storm-surge hazard in the 
coastal areas of Bangladesh. Stoch Environ Risk Assess 30:1301-1315.https://doi.org/10.1007/ s00477-016-1232-8.

Nirwandar S.2015. Ecotourism in Indonesia. Jakarta: Ministry of Tourism and Creative Economy.

Nugroho et al. 2016. Promoting the rural development through the ecotourism activities in Indonesia. American. Journal of Tourism Management 5 (1): 9-18

Nurhayati A, Aisah I, Supriatna AK. 2019. Model development of a synergistic sustainable marine ecotourism: A case study in Pangandaran Region, West Java Province, Indonesia. Sustainability 11(12):3418.

Prasetiamartati B, Fauzi A, Dahuri R Fahrudin A, Lange H. 2006. Destructive Fishery and Fishery Sustainability Assessing Fishery Sustainability Using A Multicriteria Participatory Approach: A Case Study of Small Islands in South Sulawesi. Journal of Coastal Development 9(3):163-174.

Arroyo AS, Fernández DR. 2016. Local ecological knowledge concurs with fishing statistics: An example from the abalone fishery in Baja California, Mexico. Marine Policy 71: 217-221. https://doi.org/10.1016/j.marpol.2016.06.006.

Saragih S, Lassa J, Ramlan A. 2007. Kerangka penghidupan berkelanjutan, sustainable livelihood framework. https://www.zef.de. [10 Jan 2019].
Stanford R J, Wiryawan B, Bengen D G, Febriamansyah R, Haluan J. 2017. The fisheries livelihoods resilience check (FLIRES check): a tool for evaluating resilience in fisher Communities. Fish and Fisheries 18(6):1011-1025.

Tiypan C, Mee-Udon F. 2014. Dynamic livelihood strategies of fishery communities in Ban Don Bay, Surathani, Thailand. Khon Kaen University. International Journal of Asian Science 4(11):1126-1138.

Triyanto R, Firdaus M. 2016. Tingkat kesejahteraan nelayan skala kecil dengan pendekatan penghidupan berkelanjutan di Kabupaten Indramayu. Jurnal Sosial Ekonomi Kelautan dan Perikanan 11(1):29-43. https://doi. org/10.15578/jsekp.v11i1.3170.

Udayakumura EPN, Shresta R. 2011. Assessing livelihood for improvement: samanalawewa reservoir environs, Sri Lanka. The International Journal of Sustainable Development and World Ecology 18(4):336-376.https://doi.org/10.1080/ 13504509.2011.562740.

Widyastuti SA. 2017. Analisis dampak normalisasi daerah aliran sungai (DAS) ciliwung terhadap masyarakat kampung pulo di DKI Jakarta [Skripsi]. Bogor: Institut Pertanian Bogor.

Yulianda F. 2007. Ekowisata bahari sebagai alternatif pemanfaatan sumber daya pesisir berbasis konservasi [thesis]. Bogor: Sekolah Program Pascasarjana, Institut Pertanian Bogor. 